\title{
Experimental Investigations on Manifold Injection of Diesel and Biodiesel in a HCCI Engine with Inlet Charge Heating
}

\author{
S. B. Nagesh ${ }^{1}$, N. R. Banapurmath ${ }^{2 *}$, T. K. Chandrashekhar ${ }^{3}$, S. V. Khandal ${ }^{2}$ \\ ${ }^{1}$ Department of Mechanical Engineering, Channabasaveshwara Institute of Technology, Gubbi, Karnataka, INDIA \\ ${ }^{2}$ Department of Mechanical Engineering, B.V.B. College of Engineering and Technology, Hubli, KLE Technological \\ University, Karnataka, INDIA \\ ${ }^{3}$ Mangalore Institute of Tecbnology \& Engineering (MITE), Moodabidri-574227, Karnataka, INDIA
}

*Corresponding Author: nrbanapurmath@gmail.com

Citation: Nagesh, S. B., Banapurmath, N. R., Chandrashekhar, T. K. and Khandal, S. V. (2018). Experimental Investigations on Manifold Injection of Diesel and Biodiesel in a HCCI Engine with Inlet Charge Heating. European Journal of Sustainable Development Research, 2(4), 45. https://doi.org/10.20897/ejosdr/3913

Published: October 4, 2018

\begin{abstract}
In the present study, engine tests were conducted on a modified single cylinder four stroke compression ignition (CI) engine operated in homogeneous charge compression ignition (HCCI) mode with injection of diesel and biodiesels through intake manifold. The intake air temperature varied from 50 to $80{ }^{\circ} \mathrm{C}$ for diesel and 55 to $85^{\circ} \mathrm{C}$ for biodiesel using air pre heater. The coolant temperature varied from 40 to $60^{\circ} \mathrm{C}$ for both the diesel and biodiesel operation. For the comparison purpose, CI engine fuelled with diesel was operated at the injection timing of $23^{\circ} \mathrm{BTDC}$ and an injector pressure of $205 \mathrm{bar}$. It is seen that HCCI mode of engine operation with diesel and biodiesel resulted into 35-45\% lower brake thermal efficiency (BTE) with significant reduction in nitrogen oxide $\left(\mathrm{NO}_{\mathrm{x}}\right)$ emission by $98 \%$ and smoke emissions by $65-75 \%$. On the other hand, HCCI engine operation with diesel and biodiesels showed increased hydrocarbon (HC) emissions by $20-25$ times and carbon monoxide (CO) emissions by $30-40 \%$. However, peak pressure (PP) and heat release rate (HRR) decreased by $20-25 \%$ when compared to CI mode of engine operation.
\end{abstract}

Keywords: homogeneous charge compression ignition (HCCI), air preheater, manifold injection, emissions

\section{INTRODUCTION}

CI engines are highly efficient in terms of fuel economy but emit more $\mathrm{NO}_{\mathrm{x}}$ and smoke emissions in the exhaust. Biodiesels can be used in CI engine as they have similar properties as that of diesel. However, biodiesels demands higher injector opening pressure (IOP) as they have higher viscosity compared to diesel. Use of biodiesel in CI engine addresses the scarcity of fuel but to meet the emission norms led by the authorities, it is necessary to use new concept which meets the legal limits of authority.

HCCI concept is the one to address both of them simultaneously. HCCI concept of combustion started during the late 1970 and this relatively newer concept employment in CI engine in commercial applications is due to its potential to achieve better BTE and lower emissions. In this concept, a homogeneous air-fuel mixture auto-ignites at number of places by compression alone when it reaches the chemical activation energy (Pucher et al., 1996; Furutani et al., 1993).

HCCI engine operation with diesel fuel at different compression ratio (CR) was performed and it was observed that with an inlet air temperature of $90^{\circ} \mathrm{C}$, diesel fuel requires about 11:1 compression ratio to ignite it at top dead 
centre (TDC) (Christensen et al., 1999). HCCI operation has a potential for resulting very low $\mathrm{NO}_{\mathrm{x}}$ and particulate matter (PM) emissions with high HC emission, non-optimal combustion phasing, poor BTE of $28 \%$ lower than the conventional CI mode (Yao et al., 2009). A gasoline type injector was employed to inject diesel fuel at 50 bar into the intake manifold and found very early combustion phasing at higher CR, sever knocking at higher loads and higher HC, poorer BTE (Suzuki et al., 1998). A study on the diesel HCCI engine using fuel vaporizer technology revealed that $\mathrm{NO}_{\mathrm{x}}$ and $\mathrm{PM}$ emissions were found lower, while $\mathrm{HC}$ and $\mathrm{CO}$ emissions found higher with lower indicated thermal efficiency and specific fuel consumption (SFC) (Agarwal et al., 2013). HCCI engine operation in a diesel engine with a fuel injection timing (IT) of $120^{\circ} \mathrm{CA}$ before top dead centre (BTDC) using a multi hole injector of small diameter was achieved with high levels of $\mathrm{HC}$ about $8000 \mathrm{ppm}$ and very early combustion phasing (Nakagome et al., 1997).

To avoid wall wetting (Iwabuchi et al., 1999), developed impinging sprays and found that spray angle of $80^{\circ}$ was the most suitable with ITs of 40 to $60^{\circ}$ BTDC and revealed that very high smoke opacity and high HC emissions and SFC.

Utilization of the heat energy contained in exhaust gases to vaporize the fuel and adjustment in valve overlap to get high internal EGR techniques were used and this work reported that high negative valve overlap (NVO) increased the combustion stability, low $\mathrm{NO}_{\mathrm{x}}$ and smoke at low loads and $\mathrm{NO}_{\mathrm{x}}$ increased at high outputs due to uncontrolled knocking combustion (Shi et al., 2005). Use of early in cylinder injection in HCCI engine operation revealed that engine was able to operate at lower brake mean effective pressure (BMEP) (2.1 bar to $4.3 \mathrm{bar}$ ) with low $\mathrm{NO}_{\mathrm{x}}$ emission and poor BTE but with high HC, CO and smoke emissions (Nathan et al., 2010).

The combined manifold and in cylinder injected HCCI operation was employed, where a homogeneous mixture was obtained by injecting maximum quantity of fuel into the intake manifold. The mixture was ignited by a small quantity of fuel injected directly into the cylinder and reported that both $\mathrm{NO}_{\mathrm{x}}$ and smoke emissions were better than ordinary diesel engine (Suzuki et al., 1997a; Suzuki et al., 1997b; Suzuki et al., 1998; Odaka et al., 1999). Employment of external mixture preparation device in HCCI engine operation at CR of 18 resulted in lower levels of $\mathrm{NO}_{\mathrm{x}}$ and smoke emissions with good BTE (Midlam-Mohler, 2004). Expansion of HCCI engine operating range using charge stratification revealed that the combustion becomes more stable but heat release rate (HRR) decreases and main HRR advances with large stratified charge (Berntsson and Denbratt, 2007). Supplying gasoline through intake manifold to control combustion and diesel fuel direct injection into the cylinder to initiate combustion showed that engine operating load can be increased to 12 bar indicated mean effective pressure(IMEP) with lower $\mathrm{NO}_{\mathrm{x}}$ and smoke emissions (Inagaki and Fuyuto, 2006). The characteristics and importance of heat transfer phenomena in combustion chamber walls were reported. Minimum correction coefficient for heat transfer correlations was determined theoretically under the same operating conditions. The study suggest that the proposed model could predict results better than Eichelberg's heat transfer coefficient equation and Burnt's specific heat ratio equation at all ignition timings with all fuels selected (Gürbüz, 2016). The utilization of after treatment devices plays very important role in decreasing emissions. But these can increase and decrease the $\mathrm{CO}_{2}$ emissions depending on the type of fuel and engine loads. The maximum fuel consumptions was more for biodiesel as compared to diesel. BDF100 was most sustainable at any engine load, with/without after treatment options (Caliskan and Mori, 2017). The effect of cetane number (CN) and ignition delay (ID) on the energy and exergy efficiencies of IC engine was studied. It is reported that a lower CN, a longer ID and a higher level of premixed combustion could increase the exergetic efficiency of a diesel engine (Tat, 2011). The specific fuel consumptions (SFC) decrease for all test fuels with increase in engine load. It was revealed that NO emissions increased with lower CO as amount of biodiesel in the test fuels (Uyumaz et al., 2014). Combustion duration (CD) and the cyclic variation in hydrogen run SI engine could be reduced with optimum swirling flow. The combustion stability in hydrogen run SI engine is mainly dependent on cyclic variations in the flame initiation period and the cyclic variations in this period can be reduced with controlled swirling flow (Gurbuz et al., 2014). Ethanol has higher latent het of evaporation and octane number besides its higher flammability temperature. These characters have better influence on the engine performance and reduce exhaust emissions. Engine torque increase with lower SFC was observed with the ignition timings (Calam et al., 2013).

From the detailed literature review undertaken it was observed that scanty work on low temperature combustion studies using renewable fuels like biodiesel has been reported. Hence the objective of the present study is to evaluate performance of HCCI engine fueled with Ceiba Pentandra Oil Methyl Ester (CPOME) using different coolant and intake charge temperatures.

Therefore, an attempt has been made to evaluate the performance of HCCI engine with different operating strategies. 


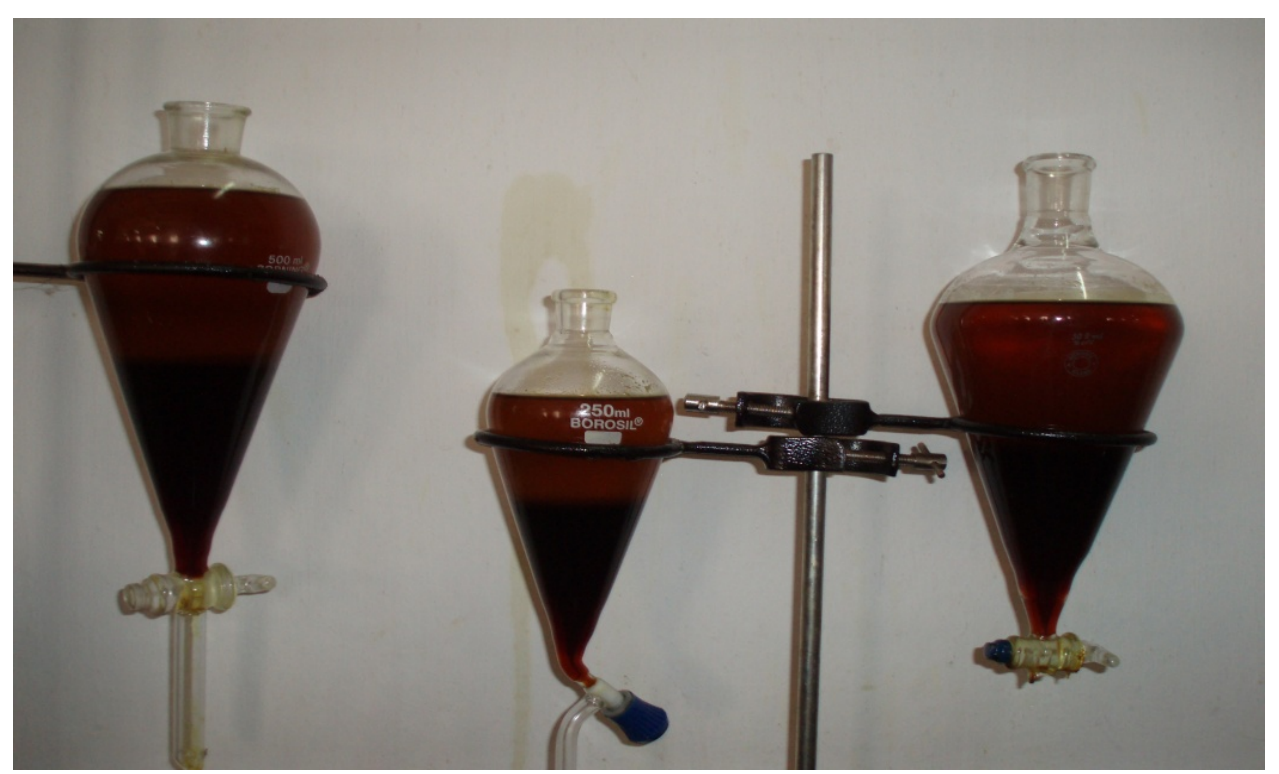

Figure 1. Separation of Biodiesel and glycerin

Table 1. Properties of Diesel, and CPOME

\begin{tabular}{clcc}
\hline S1. No. & Properties & Diesel & CPOME \\
\hline 1 & Chemical Formula & C13H24 & - \\
\hline 2 & Density $\left(\mathrm{kg} / \mathrm{m}^{3}\right)$ & 43,000 & 884.4 \\
\hline 3 & Calorific value $(\mathrm{kJ} / \mathrm{kg})$ & $2-5$ & 39,790 \\
\hline 4 & Viscosity at $40^{\circ} \mathrm{C}(\mathrm{cSt})$ & 75 & 202.5 \\
\hline 5 & Flash point $\left({ }^{\circ} \mathrm{C}\right)$ & $45-55$ & 42.4 \\
\hline 6 & Cetane Number & 0.1 & 0.06 \\
\hline 7 & Carbon Residue $(\%)$ & -2 & -5 \\
\hline 8 & Cloud point & -5 & \\
\hline
\end{tabular}

\section{PROPERTIES OF FUELS USED}

\section{Preparation of Ceiba Pentandra Oil Methyl Ester (CPOME)}

Three stages are involved in transesterification of Ceiba Pentandra Oil (CPO). The acid transesterification and alkali transesterification stages are required for production of CPOME. Following steps explain an optimized method of production of CPOME.

First Stage: In the first stage $2000 \mathrm{ml}$ of raw $\mathrm{CPO}$ is heated up to $105^{\circ} \mathrm{C}$ in a round bottom flask in order to remove the moisture content. Then the oil sample is titrated against $\mathrm{NaOH}$ solutions to calculate Free Fatty Acid (FFA) and it was about $8 \%$.

Second Stage: In the second stage $1000 \mathrm{ml}$ of moisture-free $\mathrm{CPO}$ is heated to $60^{\circ} \mathrm{C}$ and then $150 \mathrm{ml}$ of methanol \& $1.5 \mathrm{ml}$ of sulphuric acid are added to the oil. The obtained solution is stirred vigorously using magnetic stirrer at $450 \mathrm{rpm}$ for approximately one hour. Then the solution so obtained is then allowed to settle for about eight hours and the top layer which contains acid is removed. Residue oil is tested for FFA and it was about 5.6\%. Since the value was higher than required, the above procedure was repeated until the FFA value was $2.8 \%$.

Third Stage: In the third stage the residue oil is heated to a temperature of $60^{\circ} \mathrm{C} .100 \mathrm{ml}$ of methanol and 7.6 grams of $\mathrm{NaOH}$ are added to the residue oil. The resulting mixture is maintained at the same temperature and stirred at $450 \mathrm{rpm}$. After 90 minutes, the mixture is transferred to separating funnel for settling under gravity as shown in Figure 1. After eight hours, heavier part glycerin which settled at lower level is separated out to obtain methyl ester of CPO which is further washed with water for 3 or 4 times with a solution containing $10 \mathrm{ml}$ of acetic acid and hot water to remove moisture and other sediments to obtain clean CPOME. The biodiesel yield per 1000 $\mathrm{ml}$ oil was found to be $890 \mathrm{ml}$ or $89 \%$.

The properties of CPOME was determined in the fuel testing laboratory and summarized in Table 1. 


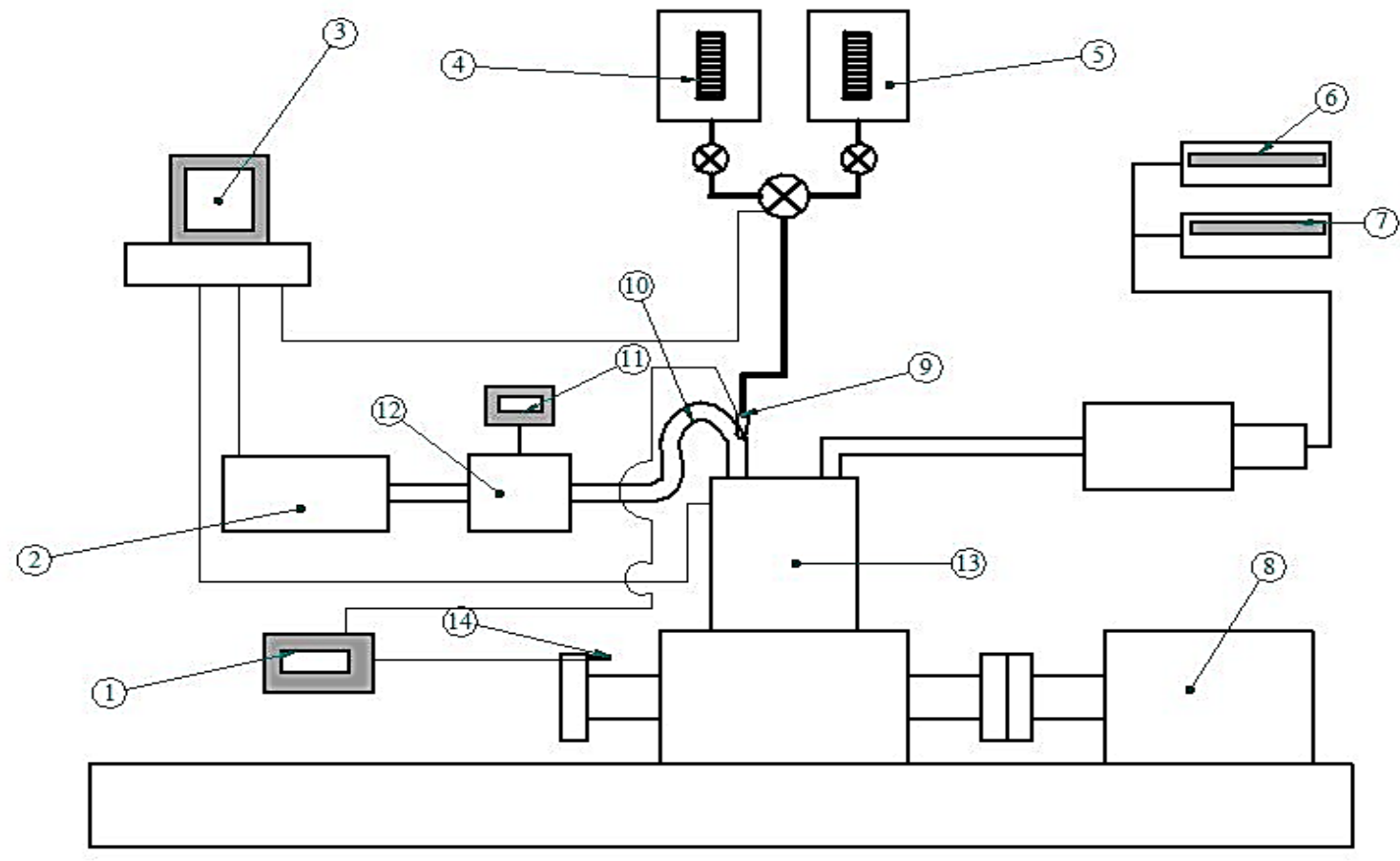

01. Injector ECU

02. Air box

03. PC interfaced to engine

04. Diesel tank

05. Biodiesel tank
06. Exhaust gas analyzer

07. Smoke meter

08. Eddy current dynamometer

09. Fuel injector

10. Intake manifold
11. Temperature controlling unit

12. Electric air heater

13. CI engine

14. Crank angle sensor

Figure 2. Experimental set up with Manifold injection facility

\section{EXPERIMENTAL SET UP AND METHODOLOGY ADOPTED}

\section{Manifold Injection of Diesel and Biodiesel}

The conventional diesel engine was suitably modified to operate in HCCI mode. Air-preheater was used to supply hot air and manifold fuel injection facility developed in house was used to inject diesel and biodiesels with a pintle nozzle at an opening pressure of $100 \mathrm{bar}$ for diesel and $130 \mathrm{bar}$ for the biodiesel respectively at IT of $40^{\circ}$ ATDC that is during the suction stroke. A separate inline injection facility that operates with the help of cam shaft was developed in house. This facility provides an opportunity to set IT at any desired value with external mechanical arrangement developed. Actual start of fuel IT was obtained with the help of a needle lift sensor. The engine was always operated at BMEP of 2.5 bar ( $50 \%$ load). The coolant temperature was controlled by varying the water flow rates with the help of a flow control valve. The temperature of cooling water was measured with the help of thermocouples. The experimental set up for HCCI engine operation fuelled with diesel and biodiesels is shown in Figure 2. Table 2 shows the specification of the engine used. Specification of smoke meter is given in Table 3 and the specification of exhaust gas analyzer is given in Table 4. Exhaust gas analyzer and Hartridge smoke meter were used in order to measure $\mathrm{HC}, \mathrm{NO}_{x}, \mathrm{CO}$ and smoke emissions respectively. The effect of charge temperature on emissions and performance characteristics of HCCI engine was studied. 
Table 2. Engine specifications

\begin{tabular}{cll}
\hline SI. No & Parameter & Specifications \\
\hline 1 & Type & TV1 (Kirlosker make) \\
\hline 2 & Software used & Engine soft \\
\hline 3 & Nozzle opening pressure & 200-225 bar \\
\hline 4 & Governor type & Mechanical centrifugal type \\
\hline 5 & No. of cylinders & Single cylinder \\
\hline 6 & No. of strokes & Four stroke \\
\hline 7 & Fuel & H. S. Diesel \\
\hline 8 & Rated power & $5.2 \mathrm{~kW}(7 \mathrm{HP}$ at 1500 RPM) \\
\hline 9 & Cylinder diameter (Bore) & $0.0875 \mathrm{~m}$ \\
\hline 10 & Stroke length & $0.11 \mathrm{~m}$ \\
\hline 11 & Compression ratio & $17: 5: 1$ \\
\hline Air measurement manometer & \\
\hline 12 & Made & MX 201 \\
\hline 13 & Type & U-Type \\
\hline 14 & Range & $100-0-100 \mathrm{~m}$ \\
\hline Eddy current dynamometer & \\
\hline 15 & Model & AG-100 \\
\hline 16 & Type & Eddy current \\
\hline 17 & Maximum & $7.5(\mathrm{~kW}$ at $1500-3000$ RPM $)$ \\
\hline 18 & Flow & Water must flow through Dynamometer during the use \\
\hline 19 & Dynamometer arm length & $0.180 \mathrm{~m}$ \\
\hline 20 & Fuel measuring unit - Range & $0-50 \mathrm{ml}$ \\
\hline
\end{tabular}

Table 3. Specifications of smoke meter

Type

Object of measurement

Measuring range opacity

Accuracy

Resolution

Smoke length

Ambient Temperature Range

Warm up time

Speed of response time

Sampling

Power supply

Size

\section{HARTRIDGE SMOKEMETER-4}

Smoke

$0-100 \%$

$+/-2 \%$ relative

$0.1 \%$

$0.43 \mathrm{~m}$

$-0 \mathrm{oC}$ to $+45 \mathrm{oC}$

10 min. (self controlled) at $20 \mathrm{oC}$

Within 15 sec. for $90 \%$ response

Directly sampled from tail pipe

100 to $240 \mathrm{~V} \mathrm{AC} \mathrm{/} \mathrm{50HZ}$

10-16 V DC @ 15 amps

$100 \mathrm{~mm} \times 210 \mathrm{~mm} \times 50 \mathrm{~mm}$

Table 4. The accuracies of the measurements and the uncertainties in the calculated parameter

Type

Object of measurement

Range of measurement

Accuracy

Resolution

Warm up time

Speed of response time

Sampling

Power source

Weight

Size
DELTA 1600S

Carbon monoxide (CO) and Hydrocarbons (HC)

$\mathrm{HC}=0$ to $20.000 \mathrm{ppm}$ as $\mathrm{C} 3 \mathrm{H} 8$ (Propane)

$\mathrm{CO}=0$ to $10 \%$

$\mathrm{NO}_{\mathrm{x}}=0$ to $5000 \mathrm{ppm}$ (as Nitric Oxide)

$\mathrm{HC}=+/-30 \mathrm{ppm} \mathrm{HC}$

$\mathrm{CO}=+/-0.2 \% \mathrm{CO}$

$\mathrm{NO}_{\mathrm{x}}=+/-10 \mathrm{ppm} \mathrm{NO}$

$\mathrm{HC}=1 \mathrm{ppm}$

$\mathrm{CO}=0.01 \% \mathrm{Vol}$

$\mathrm{NO}_{\mathrm{x}}=1 \mathrm{ppm}$

$10 \mathrm{~min}$. (self-controlled) at $20 \mathrm{oC}$

Within $15 \mathrm{sec}$. for $90 \%$ response

Directly sampled from tail pipe

100 to $240 \mathrm{~V} \mathrm{AC} / 50 \mathrm{~Hz}$

$800 \mathrm{gm}$

$100 \mathrm{~mm} \times 210 \mathrm{~mm} \times 50 \mathrm{~mm}$ 
Table 5. The accuracies of the measurements and the uncertainties in the calculated parameter

\begin{tabular}{ll}
\hline Measured variable & Accuracy \\
\hline Load, $\mathrm{N}$ & 0.1 \\
\hline Engine speed, rpm & 1 \\
\hline Temperature, ${ }^{\circ} \mathrm{C}$ & 1 \\
\hline Fuel consumption, $\mathrm{g}$ & 0.1 \\
\hline Measured variable & Uncertainty (\%) \\
\hline $\mathrm{HC}$ & \pm 1.5 \\
\hline $\mathrm{CO}$ & \pm 2.1 \\
\hline NO $\mathrm{x}_{\mathrm{x}}$ & \pm 2.4 \\
\hline Calculated parameters & Uncertainty (\%) \\
\hline BTE $(\%)$ & \pm 0.9 \\
\hline
\end{tabular}

\section{Experimental Uncertainty Analysis}

The accuracies of the measurements and the uncertainties in the calculated values of each parameters of the current investigation are shown in the Table 5. In order to minimize the errors of measurements five readings were recorded and averaged out results are only presented for the analysis. All the measurements of physical quantities are subject to uncertainties and were estimated as below:

\section{Uncertainty in the of Mass Flow Rate of Fuel $\left(m_{f}\right)$}

Mass flow rate of fuel, $m_{f}$

i.e,

$$
m_{f}=\frac{\text { Volume flow rate of fuel in cc } \times 10^{-6} \times \text { Density of fuel }}{\text { Time taken in seconds }}
$$

$$
m_{f}=\frac{V_{f} \times 10^{-5} \times \rho_{f}}{t}
$$

Volume flow rate of rate of fuel is measured using burettes, so uncertainty in burette reading, $\omega_{v_{f f}}= \pm 1 \mathrm{cc}=$ $\pm 1 \times 10^{-3} \mathrm{~m}^{3}$

$$
\text { Uncertainty in } m_{f}= \pm \sqrt{\left(\frac{\partial m_{f}}{\partial V_{f}} \times \omega_{V_{f}}\right)^{2}+\left(\frac{\partial m_{f}}{\partial t} \times \omega_{t}\right)^{2}}=\mathrm{in} \mathrm{kg} / \mathrm{s}
$$

\section{Uncertainty in brake power (BP)}

Brake power of engine,

where, $W$ is Load applied in $N$;

$$
B P=\frac{2 \pi N T}{60 \times 1000}=\frac{2 \pi N \times W \times R}{60 \times 1000}=k W
$$

Uncertainty in $B P, \omega_{B P}$,

$$
\omega_{B P}= \pm \sqrt{\left(\frac{\partial B P}{\partial W} \times \omega_{W}\right)^{2}+\left(\frac{\partial B P}{\partial N} \times \omega_{N}\right)^{2}}= \pm \text { in } k W
$$

\section{Uncertainty in the brake thermal efficiency $\left(\boldsymbol{\eta}_{t h}\right)$}

Brake thermal efficiency is given by

Uncertainty in Brake thermal efficiency,

$$
\eta_{t h}=\frac{\text { Brake power in } k W}{m_{f} \times C V_{1}} \times 100=\%
$$

$$
\omega_{\eta_{t h}}= \pm \sqrt{\left[\frac{\partial \eta_{t h}}{\partial B P} \times \omega_{B P}\right]^{2}+\left[\frac{\partial \eta_{t h}}{\partial m_{f}} \times \omega_{m_{f}}\right]^{2}}= \pm \%
$$

Table 4 provides the uncertainties calculated for the parameters on performance, emission and combustion. Uncertainty values for all the parameters are within $3 \%$ and are acceptable for the analysis presented. 


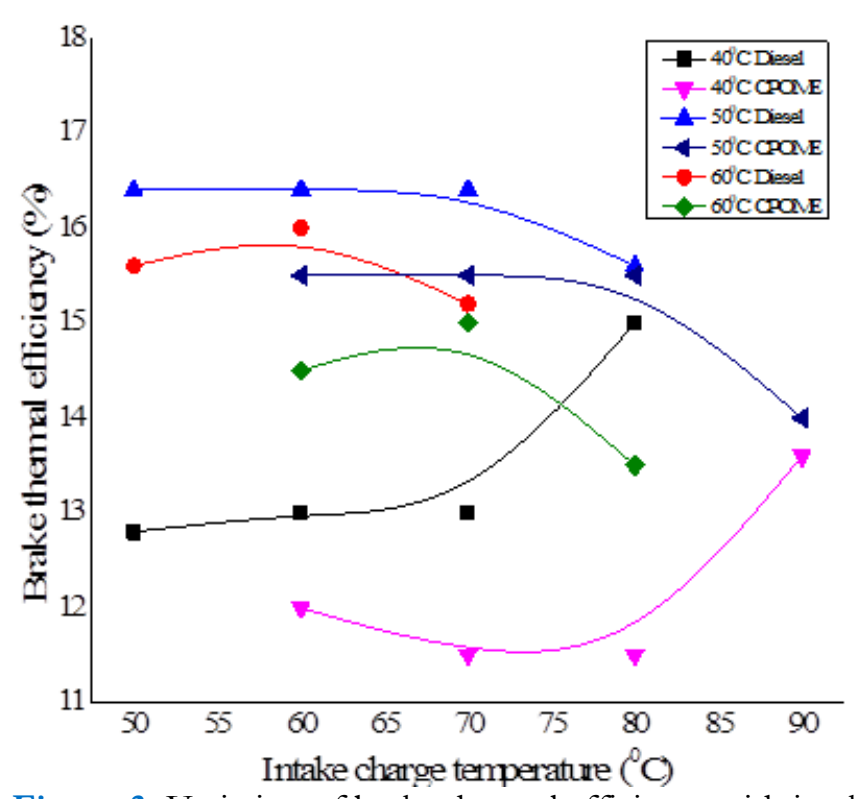

Figure 3. Variation of brake thermal efficiency with intake charge temperature

\section{RESULTS AND DISCUSSIONS}

This section discusses the results of the experiments carried out using diesel and biodiesel in manifold assisted HCCI mode of engine operation.

\section{Brake Thermal Efficiency}

Figure 3 shows the effect of charge and coolant temperatures on BTE in case of manifold injection of diesel, and CPOME. The BTE is found to be lowest with all the injected fuels for coolant temperature of $40^{\circ} \mathrm{C}$ and this is observed up to the charge temperature of $70^{\circ} \mathrm{C}$. However for coolant temperature of 50 and $60^{\circ} \mathrm{C}$, the $\mathrm{BTE}$ is much higher compared to $40^{\circ} \mathrm{C}$ but drop in BTE beyond $70^{\circ} \mathrm{C}$ is observed. Lower HRR available at lower coolant/charge temperatures could be responsible for these trends obtained. Lower coolant temperatures demands higher charge temperatures to achieve better BTE. However the injected biodiesel have shown poorer performance than the diesel and the reasons could be attributed to their higher viscosity (nearly twice), lower volatility and calorific value and also they require 5 to $10^{\circ} \mathrm{C}$ higher intake charge temperature compared to its counterpart diesel. When the coolant temperature increased is from $40^{\circ} \mathrm{C}$ to $60^{\circ} \mathrm{C}$, advancement in the main heat release for diesel and biodiesels was observed with increase in the fuel injection rate. For $40^{\circ} \mathrm{C}$ coolant temperature, when the charge temperature was increased to a value higher than $80^{\circ} \mathrm{C}$ the HRR goes up that resulted in increased BTE. The highest BTE was obtained at a coolant temperature of $50^{\circ} \mathrm{C}$ which as seen from Figure 3 and after this coolant temperature, the BTE dropped due to very early heat release. The engine became erratic due to knock at high charge temperatures of about $80^{\circ} \mathrm{C}$ for diesel and $85^{\circ} \mathrm{C}$ for biodiesels and the high coolant temperature about $60^{\circ} \mathrm{C}$ though the HRR was high, but it occurs at too early crank angles.

\section{Hydrocarbon (HC) Emissions}

Figure 4 shows the trend of $\mathrm{HC}$ emissions with varied coolant and charge temperatures. The biodiesel showed higher HC emissions compared to diesel and the reasons could be their lower BTE obtained associated with incomplete combustion that prevails inside the combustion chamber due to improper fuel-air mixture and subsequent wall wetting problem observed with these biodiesels. The trend of HC emissions was not uniform and was different for different coolant temperatures. As the coolant temperature increased the cylinder wall temperature goes up increasing the vaporization of the fuel from the wall surface. This could be a reason for increased $\mathrm{HC}$ emissions with increase in coolant temperature. Similar trends were reported in the literature. With a coolant temperature of $40^{\circ} \mathrm{C}, \mathrm{HC}$ emission decreased when the charge temperature was increased to $70^{\circ} \mathrm{C}$ then it increased. Decreasing trend of $\mathrm{HC}$ emission for the injected liquid fuels was observed at a coolant temperature of $50^{\circ} \mathrm{Cw}$ ith increase in intake charge temperature whereas at a coolant temperature of $60^{\circ} \mathrm{C}$ increasing trend was observed with increase in intake charge temperature. 


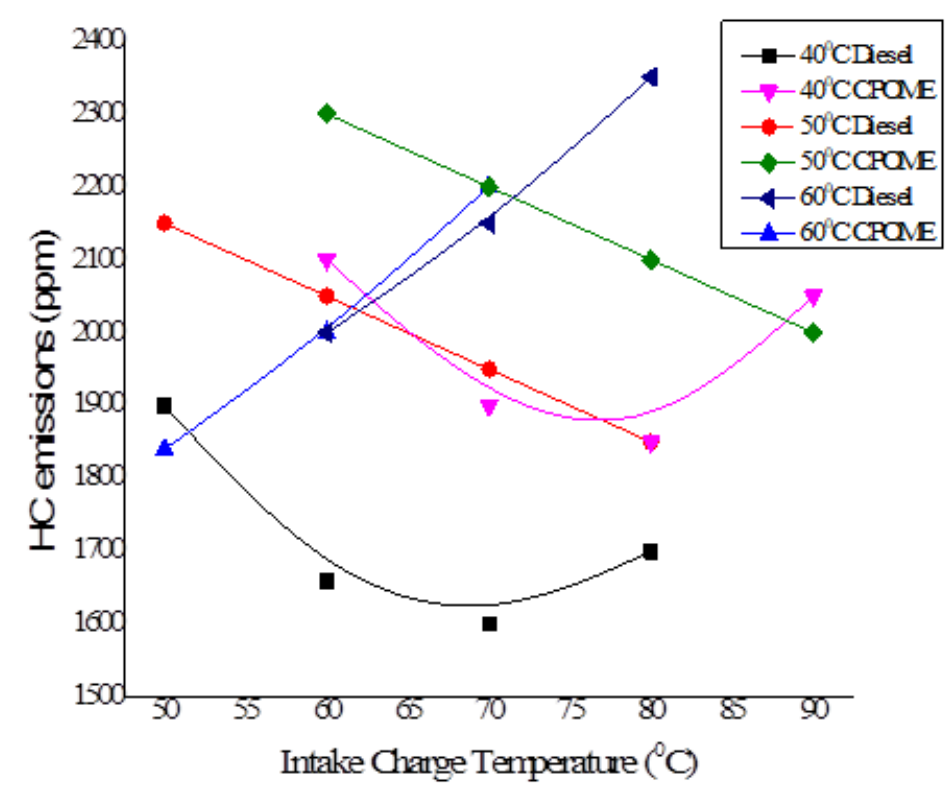

Figure 4. Variation of HC emissions with intake charge temperature

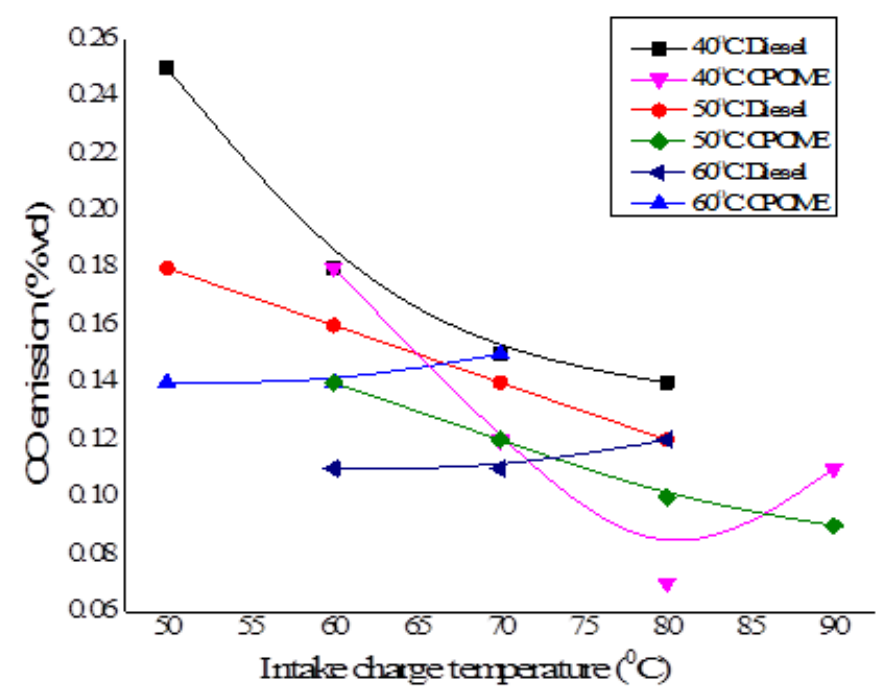

Figure 5. Variation of $\mathrm{CO}$ emissions with intake charge temperature

\section{Carbon Monoxide (CO) Emissions}

Figure 5 shows the effect of intake charge temperature and coolant temperature on $\mathrm{CO}$ emissions. CO emission showed similar trends as compared to HC emissions. The biodiesel showed higher $\mathrm{CO}$ emissions compared to diesel and the reasons could be the incomplete combustion that occurs due to improper fuel and air mixtures. With a coolant temperature of $40^{\circ} \mathrm{C}, \mathrm{CO}$ emission decreased when the charge temperature was increased up to $70^{\circ} \mathrm{C}$ than it increased. Decreasing trend of $\mathrm{CO}$ emission was observed at a coolant temperature of $50^{\circ} \mathrm{C}$ with increase in intake charge temperature whereas at a coolant temperature of $60^{\circ} \mathrm{C}$ increasing trend was observed with increase in intake charge temperature. Similar results were reported in the literature.

\section{Exhaust Gas Temperature}

The variation in exhaust gas temperature with coolant and intake charge temperature is shown in Figure 6. It is clearly observed from the Figure 6 that as the intake charge temperature increases the exhaust gas temperature (EGT) increased. Also with the increase in coolant temperature there was increase in EGT. EGT refers to the excess heat supplied to the engine cylinder and in case of biodiesel; the lower BTE has resulted into higher EGT. 


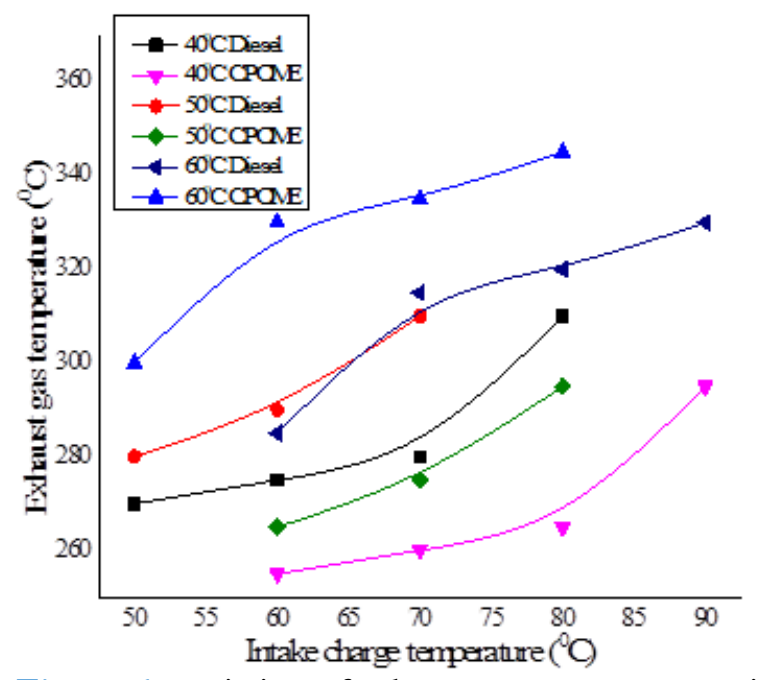

Figure 6. Variation of exhaust gas temperature with intake charge temperature

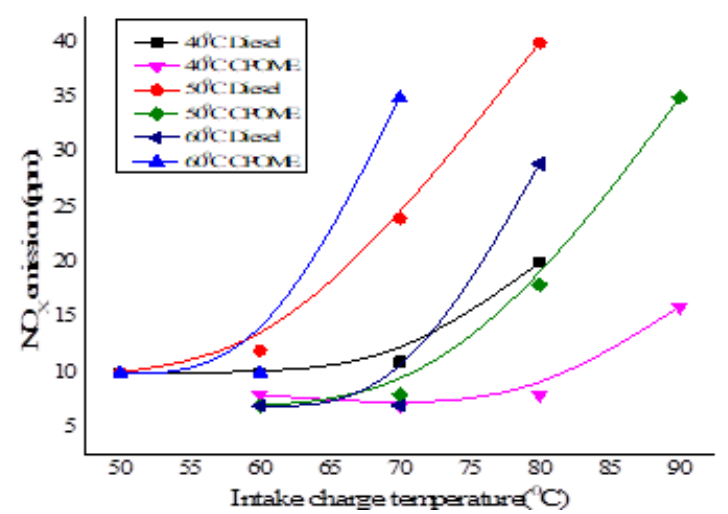

Figure 7. Variation of $\mathrm{NO}_{\mathrm{x}}$ emissions with intake charge temperature

\section{Nitrogen Oxides $\left(\mathrm{NO}_{\mathrm{x}}\right)$ Emissions}

Figure 7 shows the variation of $\mathrm{NO}_{\mathrm{x}}$ emission with intake charge temperature at different coolant temperatures. Higher combustion temperature inside the cylinder and nitrogen present in atmospheric air are the causes for $\mathrm{NO}_{\mathrm{x}}$ formations. The biodiesel showed lower $\mathrm{NO}_{\mathrm{x}}$ emissions compared to diesel. The reasons for this could be attributed to lower premixed combustion, lower peak pressure and combustion temperature occurring in the CC. The $\mathrm{NO}_{\mathrm{x}}$ emission were extremely lower compared to conventional diesel engine mode and this is mainly due to homogeneous mixture of fuel and air before combustion starts and lower in-cylinder temperature achieved. In the HCCI mode of engine operation the intake charge temperature has a significant influence on $\mathrm{NO}_{\mathrm{x}}$ emissions level. The HCCI operational ways resulted in lesser than $30 \mathrm{ppm}$ of $\mathrm{NO}_{\mathrm{x}}$ emissions but the $\mathrm{NO}_{\mathrm{x}}$ level was about 300 ppm with the base diesel engine.

\section{Smoke Emissions}

The variation of smoke emissions with intake charge temperature at different coolant temperature is shown in Figure 8. It can be observed from figure that the smoke level depends on both the charge and coolant temperatures. Smoke level was highest at the coolant temperature of $50^{\circ} \mathrm{C}$, where the BTE was reported to be highest for both diesel and biodiesels. However CPOME showed comparatively higher smoke due to their heavier molecular structure that resulted in improper fuel-air mixture compared to diesel. At the lowest coolant temperature used smoke observed was lower, probably because the temperatures were very low and in HCCI operation homogeneous charge formed led to complete combustion. At the intermediate temperature, where the BTE was highest, the smoke level was also highest. An increase in charge temperature increased the local temperature that increased the smoke level. The smoke level was quite high with the HCCI mode of operation. 


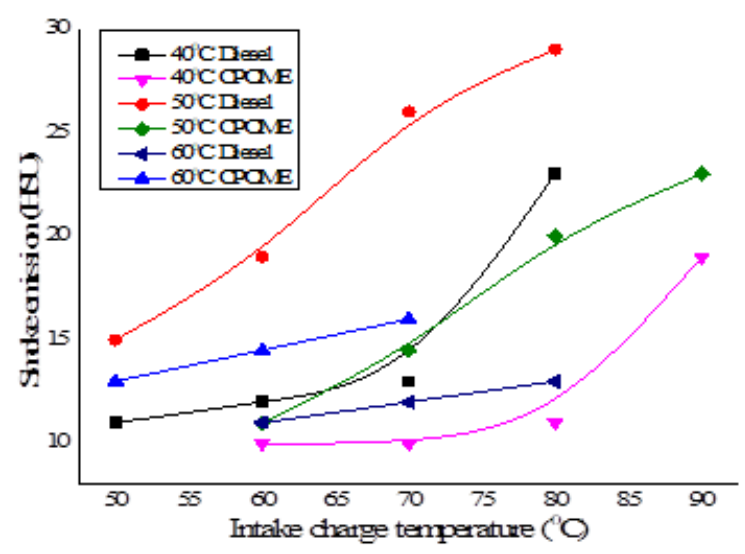

Figure 8. Variation of Smoke emissions with intake charge temperature

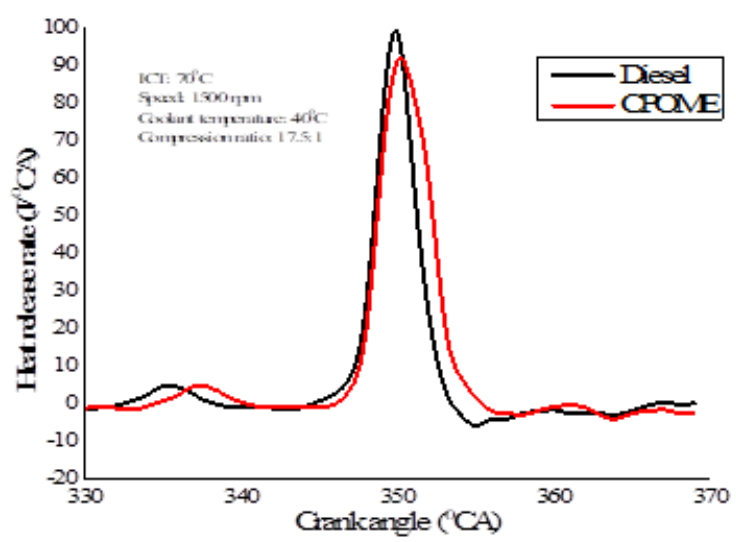

Figure 9. Variation of HRR with Crank angle

\section{Heat Release Rate (HRR)}

The account of energy supplied to charge heating is not considered in the calculations of the heat release. Figure 9 shows the variation of heat release rate with crank angle for diesel, CPOME fuelled HCCI engine for optimized conditions of intake charge temperature of $70^{\circ} \mathrm{C}$ and a coolant temperature of $50^{\circ} \mathrm{C}$. From Figure 9 it follows that the properties of the injected fuels resulted in two HRRs that is cool flame HRR and main combustion. The cool flame HRR occurs between at $332-340^{\circ} \mathrm{CA}$ and a small amount of heat energy released was found for a crank angle about $10^{\circ}$. Main combustion occurred between $348-355^{\circ} \mathrm{CA}$. Diesel fuel has higher calorific value compared to its counterpart to CPOME and hence higher premixed combustions were obtained for these fuels. The biodiesel resulted in increased diffusion combustion phase as the BTE associated with these fuel combinations were lower.

\section{Peak Pressure}

Figure 10 shows the variation of pressure with crank angle for diesel, CPOME operated HCCI engine for optimized conditions of intake charge temperature of $70^{\circ} \mathrm{C}$ and a coolant temperature of $50^{\circ} \mathrm{C}$. Diesel has higher calorific value compared to its counterpart biodiesel and hence higher peak pressure is obtained. The lower calorific value and higher viscosity of biodiesels resulted into lower peak pressures. 


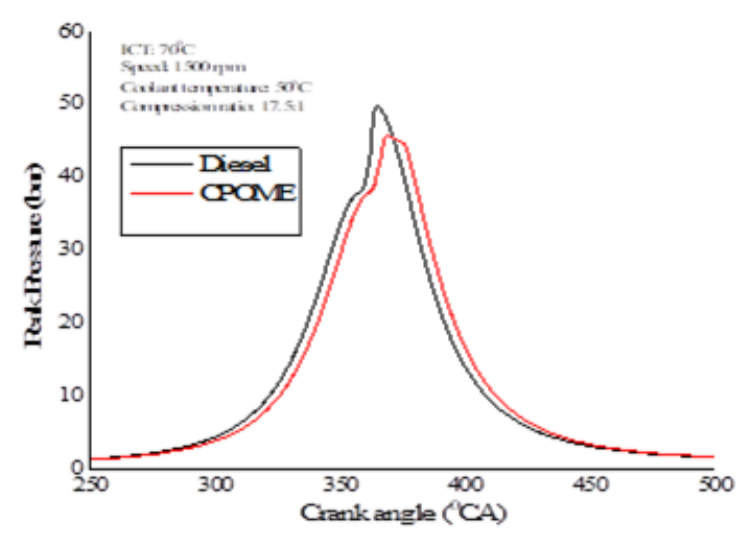

Figure 10. Variation of Peak pressure with Crank angle

\section{CONCLUSIONS}

The experiments were performed on a modified single cylinder four stroke CI engine operated in HCCI mode with injection of diesel and biodiesel through intake manifold at 50\% load. The air preheater was employed to heat the intake air and the temperature varied from 50 to $80^{\circ} \mathrm{C}$ for diesel and 55 to $85^{\circ} \mathrm{C}$ for biodiesel. The coolant temperature was varied from 40 to $60^{\circ} \mathrm{C}$ for all the fuels. For the comparison purpose, CI engine fuelled with diesel was operated at the IT of $23^{\circ} \mathrm{BTDC}$, an injector opening pressure of $205 \mathrm{bar}$, compression ratio of 17.5 and engine speed of $1500 \mathrm{rpm}$. From the experimental studies on manifold injection assisted HCCI engine fuelled with diesel and CPOME, the following conclusions are drawn under the above operating conditions:

- HCCI engine operation with diesel/biodiesel showed 35-45\% lower BTE compared to neat diesel CI engine operation.

- HCCI engine operation with diesel/biodiesel resulted in very low $\mathrm{NO}_{\mathrm{x}}$ emission about $98 \%$ lower compared to neat diesel CI engine operation.

- HCCI engine operation with diesel/biodiesel resulted in very low Smoke emission about $65-75 \%$ lower compared to neat diesel CI engine operation.

- HCCI engine operation with diesel/biodiesel resulted in lower EGT about 30-40\% lower compared to neat diesel CI engine operation.

- HCCI engine operation with diesel/biodiesel resulted in very high HC emission about 20- 25 times higher compared to neat diesel CI engine operation.

- HCCI engine operation with diesel/biodiesel resulted in very high CO emission about $30-40 \%$ higher compared to neat diesel CI engine operation.

- HCCI engine operation with diesel/biodiesel resulted in lower HRR about 20-25\% lower compared to neat diesel CI engine operation.

- HCCI engine operation with diesel/biodiesel resulted in lower PP about 20-25\% lower compared to neat diesel CI engine operation.

On the whole HCCI engine operation with diesel and biodiesel injection into manifold was successful but the main problem faced was the entry of fuels into crank case through piston-cylinder clearance. In HCCI engine operation with biodiesel intake charge temperature required was $10^{\circ} \mathrm{C}$ higher than diesel. A coolant temperature of $50^{\circ} \mathrm{C}$ and Charge temperature of $70^{\circ} \mathrm{C}$ provided overall better results.

\section{REFERENCES}

Agarwal, A. K., Singh, A. P., Lukose, J. and Gupta, T. (2013). Characterization of exhaust particulates from diesel fueled homogenous charge compression ignition combustion engine. Journal of Aerosol Sci, 58, 71-85. https://doi.org/10.1016/j.jaerosci.2012.12.005

Berntsson, A. W. and Denbratt, I. (2007). HCCI combustion using charge stratification for combustion control. SAE paper 2007-01-0210. https:// doi.org/10.4271/2007-01-0210

Calam, A., Içingür, Y., Solmaz, H. and Yamik, H. (2013). A Comparison of Engine Performance and the Emission of Fusel Oil and Gasoline Mixtures at Different Ignition Timings. International Journal of Green Energy, 12(8), 767772. https:// doi.org/10.1080/15435075.2013.849256. 
Caliskan, H. and Mori, K. (2017). Environmental, enviro-economic and enhanced thermodynamic analyses of a diesel engine with diesel oxidation catalyst (DOC) and diesel particulate filter (DPF) after treatment systems. Energy, 128. https://doi.org/10.1016/j.energy.2017.04.014

Christensen, M., Hultqvist, A. and Johansson, B. (1999). Demonstrating the multi fuel capability of a homogeneous charge compression ignition engine with variable compression ratio. SAE paper 1999-01-3679. https:// doi.org/10.4271/1999-01-3679

Furutani, M., Ohta, Y. and Komatsu, K. (1993). Onset Behavior of Low-Temperature Flames Caused by Piston Compression. JS AE Review, 14, 12-17.

Gürbüz, H., Akcay, I. H. and Buran, D. (2014). An investigation on effect of in-cylinder swirl flow on performance, combustion and cyclic variations in hydrogen fueled spark ignition engine. Joumal of the Energy Institute, 87, 110. https://doi.org/10.1016/j.joei.2012.03.001

Gürbüz, H. (2016). Parametrical Investigation of Heat Transfer with Fast Response Thermocouple in SI engine. J. Energy Eng., 142(4). https://doi.org/10.1061/(ASCE)EY.1943-7897.0000350

Inagaki, K. and Fuyuto, T. (2006). Combustion system with premixture-controlled compression ignition. R\&D Rev Toyota CRDL, 41(3), 35-46.

Iwabuchi, Y., Kawai, K., Takeshi, S. and Takeda, Y. (1999). Trial of new concept diesel combustion systempremixed compression ignition combustion. SAE paper 1999.

Midlam-Mohler, S. (2004). Diesel HCCI with external mixture preparation. 10th Diesel engine emissions reduction (DEER) workshop.

Nakagome, K., Shimazaki, N., Miimura, K. and Kobayashi, S. (1997). Combustion and emission characteristics of premixed lean diesel combustion engine. SAE paper 970898. https://doi.org/10.4271/970898

Nathan, S. S., Mallikarjuna, J. M. and Ramesh, A. (2010). An experimental study of the biogas- diesel HCCI mode of engine operation. Energy Convers Manag, 51, 1347-53. https://doi.org/10.1016/j.enconman.2009.09.008

Odaka, M., Suzuki, H., Koike, N. and Ishii, H. (1999). Search for optimizing method of homogeneous charge diesel combustion. SAE paper 1999-01-0184. https://doi.org/10.4271/1999-01-0184

Pucher, G. R., Gardiner, D. P., Bardon, M. F. and Battista, V. (1996). Alternative combustion systems for piston engines involving homogeneous charge compression ignition concepts, a review of studies using methanol, gasoline and diesel fuel. SAE paper 962063. https://doi.org/10.4271/962063

Shi, L., Deng, K. and Cui, Y. (2005). Study of diesel-fueled homogeneous charge compression ignition combustion by in-cylinder early fuel injection and negative valve overlap. P I Mech Eng D-J Aut, 219, 1193-201. https://doi.org/10.1243/095440705X34847

Suzuki, H., Koike, N. and Odaka, M. (1997a). Exhaust purification of diesel engines by homogeneous charge with compression ignition. Part 1: experimental investigation of combustion and exhaust emission behavior under pre-mixed homogeneous charge compression ignition method. SAE paper 970313.

Suzuki, H., Koike, N. and Odaka, M. (1997b). Exhaust purification of diesel engines by homogeneous charge with compression ignition. Part 2: analysis of combustion phenomena and NOx formation by numerical simulation with experiment. SAE paper 970315.

Suzuki, H., Koike, N. and Odaka, M. (1998). Combustion control method of homogeneous charge diesel engines. SAE paper 980509. https://doi.org/10.4271/980509

Takeda, Y. and Keiichi, N. (1996). Emission characteristics of premixed lean diesel combustion with extremely early staged fuel injection. SAE paper 961163. https:// doi.org/10.4271/961163

Tat. M. E. (2011). Cetane number effect on the energetic and exergetic efficiency of a diesel engine fueled with biodiesel. Fuel Processing Technology, 92, 1311-1321. https:// doi.org/10.1016/j.fuproc.2011.02.006

Uyumaz, A., Solmaz, H., Yilmaz, E., Yamik, H. and Polat, S. (2014). Experimental examination of the effects of military aviation fuel JP-8 and biodiesel fuel blends on the engine performance, exhaust emissions and combustion in a direct injection engine. Fuel Processing Technology, 128, 158-165. https://doi.org/10.1016/j.fuproc.2014.07.013

Yao, M., Zheng, Z. and Liu, H. (2009). Progress and recent trends in homogeneous charge compression ignition (HCCI) engines. Progress in Energy and Combustion Science, 35, 398-437. https://doi.org/10.1016/j.pecs.2009.05.001 